\title{
PSA Level 0.2 to Four
}

National Cancer Institute

\section{Source}

National Cancer Institute. PSA Level 0.2 to Four. NCI Thesaurus. Code C153411.

A blood concentration of prostate specific antigen between $0.2 \mathrm{ng} / \mathrm{mL}$ and $4 \mathrm{ng} / \mathrm{mL}$. 